\title{
Efficacy of Botanical Insecticides against the Pea Aphid, Acyrthosiphon pisum (Harris) and Effect on Some of Its Natural Enemies on Field Pea in South Central Ethiopia
}

\author{
Lemmessa Gemmeda $^{1^{*}}$ and Gashawbeza Ayalew ${ }^{2}$ \\ ${ }^{1}$ College of Agriculture and Environmental Science, Arsi University, P.O Box: 193, Asela, Ethiopia \\ ${ }^{2}$ Ethiopian Institute of Agricultural Research (EIAR), Melkassa Center, Adama, Ethiopia
}

\begin{tabular}{|c|c|}
\hline Abstract & Article Information \\
\hline \multirow{14}{*}{$\begin{array}{l}\text { A field experiment was conducted at Kulumsa center of the Ethiopian Institute of Agricultural } \\
\text { Research (EIAR) during September } 2011 \text { and January } 2011 \text { to assess the efficacy of botanical } \\
\text { insecticides against the pea aphid, Acyrthosiphon pisum (Harris) on field pea (Pisum sativum) } \\
\text { and their effect on the commonly associated natural enemies of the pest. Aqueous extracts of } \\
\text { different parts of four plant species, namely pyrethrum flower (Chrysanthemum cinerariifolium } \\
\text { Trev.), young leaves of Blue Gum (Eucalyptus globulus Labill.), neem seed (Azadirachta indica } \\
\text { A. Juss) and matured leaves of Aloe (Aloe pubescens Reynolds), at two different } \\
\text { concentrations ( } 5 \text { and } 10 \% \text { ) were tested along with the standard insecticide Pirimicarb } 50 \% \text { WP } \\
\text { and untreated check on pea aphid tolerant variety (Tegegnech) and susceptible variety } \\
\text { (Mohanderfer). The experiment was laid out in randomized complete block design with three } \\
\text { replications. The lowest and highest aphid population and damage level were recorded from } \\
\text { the standard insecticide (Pirimicarb) and untreated plots, respectively. Aphid population and } \\
\text { their damage in botanical treatments were intermediate between the standard and the untreated } \\
\text { check. Eucalyptus globulus resulted in lower aphid population and damage level than the rest } \\
\text { of botanical treatments. Similarly, the lowest and highest yield were recorded from the untreated } \\
\text { and Pirimicarb treated plots, respectively. Differences between any of the botanical and } \\
\text { Pirimicarb treatments were not significant for yield ( } P>0.05 \text { ). Botanical treatments resulted in } \\
0.51 \text { to } 0.81 \text { tons/ha higher yield than the untreated check. This corresponds to a yield } \\
\text { advantage of } 21.1 \text { to } 33.5 \% \text { over the untreated control. Aphid population in variety 'Tegegnech' } \\
\text { was similar to that of the 'Mohanderfer' but damage severity was lower in 'Tegegnech'. The high } \\
\text { rate (10\%) resulted in lower pest populations, less damage and higher yield than the low rate } \\
\text { (5 \%). Predation and parasitism were relatively high in the untreated plots, intermediate in } \\
\text { botanical treated plots and low in Pirimicarb treatments suggesting that botanicals were safer } \\
\text { to the natural enemies of the pest }\end{array}$} & \\
\hline & Received : 18-04-2015 \\
\hline & : 20-06-2015 \\
\hline & Accepted : 28-06-2015 \\
\hline & Keywords: \\
\hline & Pea aphid \\
\hline & Primicarb \\
\hline & Botanicals \\
\hline & Tolerant variety \\
\hline & Susceptible variety \\
\hline & ${ }^{*}$ Corresponding Author: \\
\hline & \\
\hline & E-mail: \\
\hline & \\
\hline
\end{tabular}

\section{INTRODUCTION}

Field pea (Pisum sativum L.) is a cool season food legume providing $21-25 \%$ proteins which substitute meat and other high protein animal products for resource poor farmers (Blaine et al., 2009). In Ethiopia, it is mainly produced in mid to high lands between 1800 and $3000 \mathrm{~m}$ above sea level, in the north, south, westand central parts of the country (MoA, 2007). Ethiopia ranks first in Africa and $9^{\text {th }}$ in the world with a production volume of of 160 thousand metric tons (FAO, 1999). According to the Central statistical agency of Ethiopia, current production is estimated at 263 thousand metric tons (CSA, 2012).

Several biotic constraints limit the productivity of field pea in Ethiopia including insect pestssuch as pea aphid (A. pisum), African boll worm (Helicoverpa armgera), and pea weevil (Bruchus pisorum) and diseases such as powdery mildew (Erysiphe pisi), Rust (Uromyces pisi), and Ascochyta blight (Ascochyta pinodes) (Asfaw et al.,
1994). Pea aphid is the major constraint of field pea production worldwide. The problem of pea aphid is more severe in local cultivars reaching up to 90 to $100 \%$ infestation level in several field pea production areas of Ethiopia (Asfaw et al., 1994). Melaku (2002) reported a total crop failure in Zema valley of Gojam. Yield losses of 22 and $29 \%$ were reported from Holeta and Dembi areas, respectively (IAR, 1987) and a yield loss of $49 \%$ was reported on pea variety 'Mohanderfer' from Arsi Zone (Kemal, 1991).Insecticidal control is the only method that field pea growers in Ethiopia have been using to minimize the damage inflicted by this pest. Several drawbacks are associated with the use of pesticides in pea aphid management similar to sole dependence on chemical control of other crop pests (Rajinder and Ashok, 2009). Non chemical management options offer a sustainable alternatives and strengthen integrated pest management program. Plant based insecticides form an integral 
Lemmessa Gemmeda \& Gashawbeza Ayalew

component in nonchemical methods of pest management (Dodia et al., 2008).

Extracts from some plant species have been tested against the pea aphid in Ethiopia and resulted in varying level of control. These include the hot pepper (Capsicum sp.) (Melaku, 2004). Birbira (Milletia ferruginea) seed extract (Bayeh, 2007), Neem seed oil (Azadirachta indica) (Kemal, 2002). Several plant species with pesticidal properties reported elsewhere for pest control (Pavela, 2009) are abundant in Ethiopia. Among these are pyrethrum (Chrysanthemum cinerariifolium Trev.), blue gum (Eucalyptus globulus Labill.), and Aloe (Aloe pubescens Reynolds), This study was therefore conducted to assess the efficacy of aqueous extracts of different parts of these plant species in controlling the pea aphid and their effect on commonly associating natural enemies with the aim of strengthening pea aphid integrated pest management program (IPM).

\section{MATERIALS AND METHODS}

The study was conducted at Kulumsa Agricultural Research Center located at $8^{0} 00^{\prime}-8^{0} 02^{\prime} \mathrm{N}$ and $39^{\circ} 07^{\prime}$ $39^{\circ} 10^{\prime} \mathrm{E}, 2210$ m.a.s.I in Arsi Adminstrative Zone of Oromia Regional State. The area is wet with $809 \mathrm{~mm}$ mean annual rain fall and maximum and minimum temperatures of 23.08 and $9.9{ }^{\circ} \mathrm{C}$, respectively (Abayneh et al., 2003).

\section{Collection and Preparation of Botanical Plant Materials}

Botanical plants namely pyrethrum flower (C. cinerariifolium) and young leaves of Blue gum ( $E$. globulus) were collected from the compound of Kulumsa Agricultural Research Centre. Neem seed ( $A$. indica) was collected from Dire Dawa areaand matured leaves of $A$. pubescens, were collected from Dheera in Arsi Zone. The collected plant materials were thoroughly washed by sterile tap water and dried under diffused light in the laboratory by spreading them thinly on a plastic tray.

\section{Extraction of Botanicals}

The dried plant materials were powdered manually using sterile iron mortar and pestle. Aqueous extracts of botanicals were prepared in plant protection laboratory of Kulumsa Agricultural Research Centre by mixing $10 \mathrm{~g}$ powder of each botanical plant in $100 \mathrm{ml}$ sterile distilled water. The mixture was allowed to stand for $48 \mathrm{hrs}$ using $500 \mathrm{ml}$ Erlenmeyer flask and shaken in between using shaker vibrating at 250 revolutions per minute. The solution was first filtered using bandage four times fold and squeezed and further filtered using $125 \mathrm{~mm}$ filter paper and centrifuged at 500 revolutions per minute for five minutes.

The residual remained beneath the test tube was removed and this gave a $10 \%$ stock solution. The product was kept in a bottle of $500 \mathrm{ml}$ capacity at room temperature in the laboratory until used. Five and $10 \mathrm{ml}$ of this stock solution were taken and further diluted to desired concentration of 5 and 10\% (Kemal, 2005; Pavela, 2009; Sharma and Gupta, 2009).

\section{Experimental Design and Treatments}

A randomized complete block design (RCBD) with three replications was used. Three factors, two pea varieties, pea aphid susceptible (Mohanderfer) and tolerant (Tegegnech) (Kemal, 2002), four botanicals and
Sci. Technol. Arts Res. J., April-June 2015, 4(2): 53-58

two rates (5 and 10\%) of applications were used. The insecticide Pirimicarb 50\% WP at recommended rate of 1 $\mathrm{kg} / \mathrm{ha}$ and untreated control were included as checks. Plot size was six rows of $4 \mathrm{~m}$ length each with a spacing of $5 \mathrm{~cm}$ between plants and $20 \mathrm{~cm}$ between rows. Spacing between plots and replications were $1 \mathrm{~m}$ and $2 \mathrm{~m}$, respectively. The spray volume per plot was $90 \mathrm{ml}$ which was determined by in situ calibration. Treatments were applied by taking $90 \mathrm{ml}$ of each of the application rate $(5$ and $10 \%$ ) per plot. One millilitre liquid soap was added as sticker before spray. Application was made using a hand held sprayer of $500 \mathrm{ml}$ capacity with cone nozzle. The spray drift between adjacent plots was controlled by covering the plots using plastic sheet. Land preparation and planting were done in August and September 2010, respectively. Fields were irrigated twice weekly using flood irrigation. Weeds were controlled by hand weeding. Diamonium phosphate (DAP) was applied at the rate of $100 \mathrm{~kg}$ per hectare at sowing. Urea was applied at $25 \mathrm{~kg}$ per hectare at seedling stage once.

\section{Data Collection}

\section{Pea Aphid Density and Damage}

Procedure followed by Melaku (2004) was used to determine aphid population, incidence and damage severity. Prior to treatment application 20 plants from the central four rows of each plot were randomly selected and tagged at seedling. Each tagged plant tip was bent and well shaken to dislodge aphid population on to a tray prepared from carton plastered inside with white plastic sheet. Aphid population on the plant were examined and mechanically removed by hand and aphid population were counted.

Incidence was recorded by taking the ratio of healthy and infested plants of the 20 tagged plants. Percentage pea aphid damage was visually assessed on plot bases using a simple scoring system of 1 to 5 (1= no damage; $2=$ up to $25 \%$ damage $; 3=25-50 \%$ damage $; 4=50-75 \%$ damage and $5=$ higher than $75 \%$ damage) (Melaku, 2004).

\section{Natural Enemy Population}

Level of pea aphid parasitism was estimated twice at flowering and pod setting based on the number of mummified aphid as a proportion of total insect number from each 20 sampled plants. Population of the most common pea aphid predator, the ladybird beetle (Adonia spp.) were counted twice at flowering and pod filling stage from the 20 tagged plants per plot.

\section{Data Analysis}

Data were analyzed using the SAS statistical software (SAS, 2002). Data were checked for normality before subjecting to ANOVA and appropriate transformations were made as needed. ANOVA was carried out to analyze data on aphid population, pea aphid natural enemies, pea aphid incidence, pea aphid damage, yield and yield components. Significant means were separated by Student-Newman Keuls (SNK) at .05 significance level.

\section{RESULTS}

Interaction effects were not significant among the factors considered in the analysis. Hence data on treatments or levels of each factor (botanicals, rate of application and variety) are presented along with values (mean and standard error) of the standard and untreated checks (Tables 1 to 3 ). 
Lemmessa Gemmeda \& Gashawbeza Ayalew

Aphid Population

Significant variation between botanical species in aphid population was observed at flowering and pod setting stages only. At both stages, the lowest and highest aphid populations were recorded from the standard insecticide (Pirimicarb) and untreated plots, respectively (Table1). Among botanicals, Eucalyptus resulted in lower aphid population than the rest followed by aloe at flowering, and neem at pod setting. Both Eucalyptus and neem resulted in significantly $(P<0.05)$
Sci. Technol. Arts Res. J., April-June 2015, 4(2): 53-58

lower aphid number than pyrethrum at pod setting stage. At flowering stage, however, only Eucalyptus resulted in significantly lower aphid number than pyrethrum. Results obtained from Eucalyptus was in general comparable to the standard insecticide indicating its potential for use in the IPM of pea aphids on field pea. The high rate application resulted in lower aphid population than the low rate in all crop growth stages considered. However, differences were significant at pod setting and maturity stages.

Table 1: Pea aphid number per 20 plants at vegetative, flowering, pod setting and maturity stages of two pea varieties treated with four different botanicals at two rates (5 and10\%) at Kulumsa

\begin{tabular}{|c|c|c|c|c|c|}
\hline \multirow[b]{2}{*}{ Treatments } & \multicolumn{4}{|c|}{ Crop growth stages } & \multirow[b]{2}{*}{ Mean } \\
\hline & Vegetative & Flowering & Pod setting & Maturity & \\
\hline Pyrethrum & $332.67 a$ & $1495.8 \mathrm{a}$ & $148.92 a$ & $205.17 a$ & $545.64 a$ \\
\hline Eucalyptus & $379.25 a$ & $1045.8 b$ & $99.83 b$ & $178.00 a$ & $425.72 a$ \\
\hline Aloe & $326.00 a$ & $1312.5 a b$ & $135.25 a b$ & $189.17 a$ & $490.73 a$ \\
\hline Neem & $439.17 a$ & $1366.8 \mathrm{ab}$ & $129.25 b$ & $185.75 a$ & $530.31 a$ \\
\hline Pirimicarb $50 \%$ wp & $376.83+48.34$ & $555 \pm 108.19$ & $95 \pm 11.68$ & $84.7 \pm 10.89$ & $277.88 \pm 59.57$ \\
\hline Water (control) & $383.50+32.61$ & $1866+394.08$ & $240+38.46$ & $320.7 \pm 52.85$ & $702.55+164.68$ \\
\hline \multicolumn{6}{|l|}{ Rates } \\
\hline $5 \%$ & $373.17 a$ & $1414.4 a$ & $129.83 a$ & $237.17 a$ & $538.64 a$ \\
\hline $10 \%$ & $365.38 a$ & $1196.0 \mathrm{a}$ & $126.79 \mathrm{~b}$ & $141.88 \mathrm{~b}$ & $457.51 a$ \\
\hline \multicolumn{6}{|l|}{ Varieties } \\
\hline Tegegnech & $456.67 a$ & $1306.6 a$ & $131.29 a$ & $193.5 a$ & $522.02 a$ \\
\hline Mohanderfer & $281.88 b$ & $1303.9 a$ & $125.33 a$ & $185.54 a$ & $474.16 a$ \\
\hline
\end{tabular}

Means within a column followed by the same letter (s) are not significantly different at $5 \%$ level of significance; Data were log transformed for ANOVA; Presented are actual values; means were separated using Student Newman Keuls multiple range test (SNK)

Aphid population recorded from 'Tegegnech' at vegetative stage was significantly higher than 'Mohanderfer' However, in all other crop growth stages, aphid populations in both varieties were similar without significant difference. Interaction effect was not significant either.

\section{Incidence}

Aphid incidence ranged between 58.33 and $84.17 \%$. The lowest incidence of $58.33 \pm 5.68 \%$ was recorded from the standard insecticide treatment followed by aloe $(78.75 \%)$ and Eucalyptus treatments (79.17\%), respectively (Table 2 ). Incidence in pyrethrum and neem treatments was similar to the untreated check. Differences between botanical species were not significant for aphid incidence. Similarly, incidence level was slightly higher in Tegegnech than in Mohanderfer but differences were not significant $(P>0.05)$. The high rate application resulted in significantly lower incidence $(75.21 \%)$ than the lower rate (87.29) (Table. 2).

Table 2: Pea aphid incidence and damage level in two pea varieties treated with four different botanicals at two rates (5 and10\%) at Kulumsa

\begin{tabular}{|c|c|c|}
\hline \multirow[t]{2}{*}{ Treatments } & \multicolumn{2}{|c|}{ Parameters } \\
\hline & Plant damage (\%) & Aphid incidence (\%) \\
\hline Pyrethrum & $73.33 a$ & $82.92 a$ \\
\hline Eucalyptus & $58.75 c$ & $79.17 a$ \\
\hline Aloe & $65.00 \mathrm{~b}$ & $78.75 a$ \\
\hline Neem & $66.67 \mathrm{~b}$ & $84.17 a$ \\
\hline Pirimicarb 50\% wp & $1.17 \pm 0.77$ & $58.33 \pm 5.68$ \\
\hline Water (control) & $83.33+2.98$ & $84.17+3.84$ \\
\hline \multicolumn{3}{|l|}{ Rates } \\
\hline $5 \%$ & $73.33 a$ & $87.29 a$ \\
\hline $10 \%$ & $58.54 b$ & $75.21 b$ \\
\hline \multicolumn{3}{|l|}{ Varieties } \\
\hline Tegegnech & $61.25 b$ & $82.50 \mathrm{~b}$ \\
\hline Mohanderfer & $70.63 a$ & $80.00 \mathrm{~b}$ \\
\hline
\end{tabular}

Means within a column followed by the same letter (s) are not significantly different at $5 \%$ level of significance; Data were arcsine transformed for ANOVA. Presented are actual values; means were separated using Student Newman Keuls multiple range test (SNK's).

\section{Damage Level}

Damage levels varied significantly $(P<0.05)$ among botanical treatments (Table 2). Eucalyptus with $58.70 \%$ damage performed better than the rest of botanical treatments. Damage level in neem and aloe was similar without significant difference between them. The lowest $(1.17 \pm 0.77 \%)$ and highest $(83.33 \pm 2.98 \%)$ damage levels were recorded from Pirimicarb treatment and untreated 
Lemmessa Gemmeda \& Gashawbeza Ayalew

control plots, respectively. On the other hand, damage level was significantly lower in Tegegnech $(61.25 \%)$ than in Mohanderfer (70.63\%). Differences were significant between the two rates with damage levels of 73.33 and $58.54 \%$ from 5 and $10 \%$ rates, respectively.

\section{Yield and Yield Components}

Yield in tons per hectare ranged between 1.47 and 2.42 among treatments. Similarly, pods per plant, seeds per pod, thousand seed weight and average seed size ranged between 6.93 and $9.75,2.81$ and $4.16,141.60$ and $161.00 \mathrm{gm}$, and 5.90 and $6.30 \mathrm{~mm}$, respectively (Table.3). Differences between botanicals were significant for seed weight and size. Differences between botanical species for number of pods per plant, seeds per pod and yield were not significant. The lowest values for all yield and yield component variables were obtained from the untreated plot and the highest were obtained from Pirimicarb treatment with the exception of seed weight
Sci. Technol. Arts Res. J., April-June 2015, 4(2): 53-58

where the highest was recorded from aloe treatment (Table 3).

Values for botanical treatments were intermediate between the untreated and Pirimicarb treatments. Seeds appeared to be lighter and smaller in the untreated plot than the rest of the treatments as measured by thousand seed weight and size. All yield and yield component values were significantly lower in the untreated plot than Pirimicarb treated plots. Values in botanical treatments were generally intermediate between the untreated and standard checks without significant difference between them for all the variabless measured with the exception of seed weight. Seed weight in pyrethrum treatment was significantly lower than aloe treatment. Yields in Aloe, neem, Eucalyptus, and pyrethrum treatments were 0.81 , $0.69,0.62$, and 0.51 tons per hectare higher than the untreated check (Table 3 ). This corresponds to a yield advantage of $33.48,28.52,25.63$ and $21.08 \%$, respectively over the untreated control.

Table 3: Yield and yield components in two pea varieties treated with four different botanicals at two rates (5 and $10 \%)$, KARC, September 2010to January 2011.

\begin{tabular}{|c|c|c|c|c|c|c|}
\hline \multirow{2}{*}{ Treatments } & \multicolumn{5}{|c|}{ Yield and yield componnts } & \multirow{2}{*}{ Mean } \\
\hline & $\begin{array}{l}\text { Number of } \\
\text { pods/plant }\end{array}$ & Seeds/pod & $\begin{array}{c}\text { Grain } \\
\text { yield(tons/ha) }\end{array}$ & $\begin{array}{c}\text { Thousand seed } \\
\text { weight(g) }\end{array}$ & $\begin{array}{c}\text { Average seed } \\
\text { size }(\mathrm{mm})\end{array}$ & \\
\hline Pyrethrum & $7.99 a$ & $3.53 a$ & $1.99 a$ & $146.9 \mathrm{~b}$ & $6.06 \mathrm{~b}$ & $33.29 a$ \\
\hline Eucalyptus & $8.91 \mathrm{a}$ & $3.78 a$ & $2.10 a$ & $151.67 b$ & $6.17 a b$ & $34.53 a$ \\
\hline Aloe & $8.76 a$ & $3.98 a$ & $2.29 a$ & $161.00 a$ & $6.26 \mathrm{ab}$ & $36.46 a$ \\
\hline Neem & $8.63 a$ & $3.94 a$ & $2.17 a$ & $150.73 b$ & $6.34 a$ & $34.36 a$ \\
\hline $\begin{array}{l}\text { Pirimicarb } \\
50 \% \mathrm{wp}\end{array}$ & $9.75 \pm 0.91$ & $4.16 \pm 0.69$ & $2.42 \pm 3.58$ & $160.30 \pm 4.17$ & $6.34 \pm 0.18$ & $36.59 \pm 1.91$ \\
\hline $\begin{array}{l}\text { Water } \\
\text { (control) }\end{array}$ & $6.93 \pm 0.83$ & $2.81 \pm 0.55$ & $1.48 \pm 2.94$ & $141.60 \pm 7.69$ & $5.93 \pm 0.14$ & $31.75+2.43$ \\
\hline \multicolumn{7}{|l|}{ Rates } \\
\hline $5 \%$ & $7.92 b$ & $3.47 \mathrm{~b}$ & $1.97 \mathrm{~b}$ & $150.02 b$ & $6.10 \mathrm{~b}$ & $33.89 b$ \\
\hline $10 \%$ & $9.22 \mathrm{a}$ & $4.14 a$ & $2.30 \mathrm{a}$ & $155.13 a$ & $6.31 \mathrm{a}$ & $35.42 \mathrm{a}$ \\
\hline \multicolumn{7}{|l|}{ Varieties } \\
\hline Tegegnech & $8.95 a$ & $4.28 a$ & $2.57 a$ & $157.62 a$ & $6.29 a$ & $35.94 a$ \\
\hline Mohanderfer & $8.19 a$ & $3.33 b$ & $1.71 \mathrm{~b}$ & $147.53 b$ & $6.12 b$ & $33.38 a$ \\
\hline
\end{tabular}

\section{Natural Enemy Population}

Number of Adonia spp. recorded per plot (20 plants) ranged between 0.67 and 2.5 at flowering and between 0.67 and 4.50 at pod setting (Figure 1). The lowest and highest numbers at both stages were recorded from the standard insecticide and untreated controls, respectively (Figure 1). Differences between botanical species for number of Adonia spp. was not significant at flowering stage $(P>0.05)$. At pod setting, Eucalyptus treatment gave significantly lower number of the predator than pyrethrum treatment. Predator numbers in aloe and neem treatments were intermediate between pyrethrum and Eucalyptus without significant difference between them. The low rate application resulted in higher number of Adonia spp. than the high rate both at flowering and pod setting stage. However, differences were significant at pod setting stage only (Figure 1).
Level of parasitism ranged from 1.17 to $3.50 \%$ at flowering and from 1.50 to $7.17 \%$ at pod setting stage as measured by the proportion of mummified aphids out of total aphids counted (Figure 1). Similar to level of predation, the standard insecticide and untreated controls gave the lowest and the highest parasitism level, respectively both at flowering and pod setting stages (Figure 1). Among botanical species, high level of parasitism was recorded from pyrethrum treatment followed by neem both at flowering and pod setting (Figure 1). The lowest was recorded from Eucalyptus treatment both at flowering and pod setting. Differences, however, were significant at flowering stage only. Similar to level of predation, parasitism was higher in the low rate of application than the high rate both at flowering $(P>0.05)$ and pod setting $(P<0.05)$. 

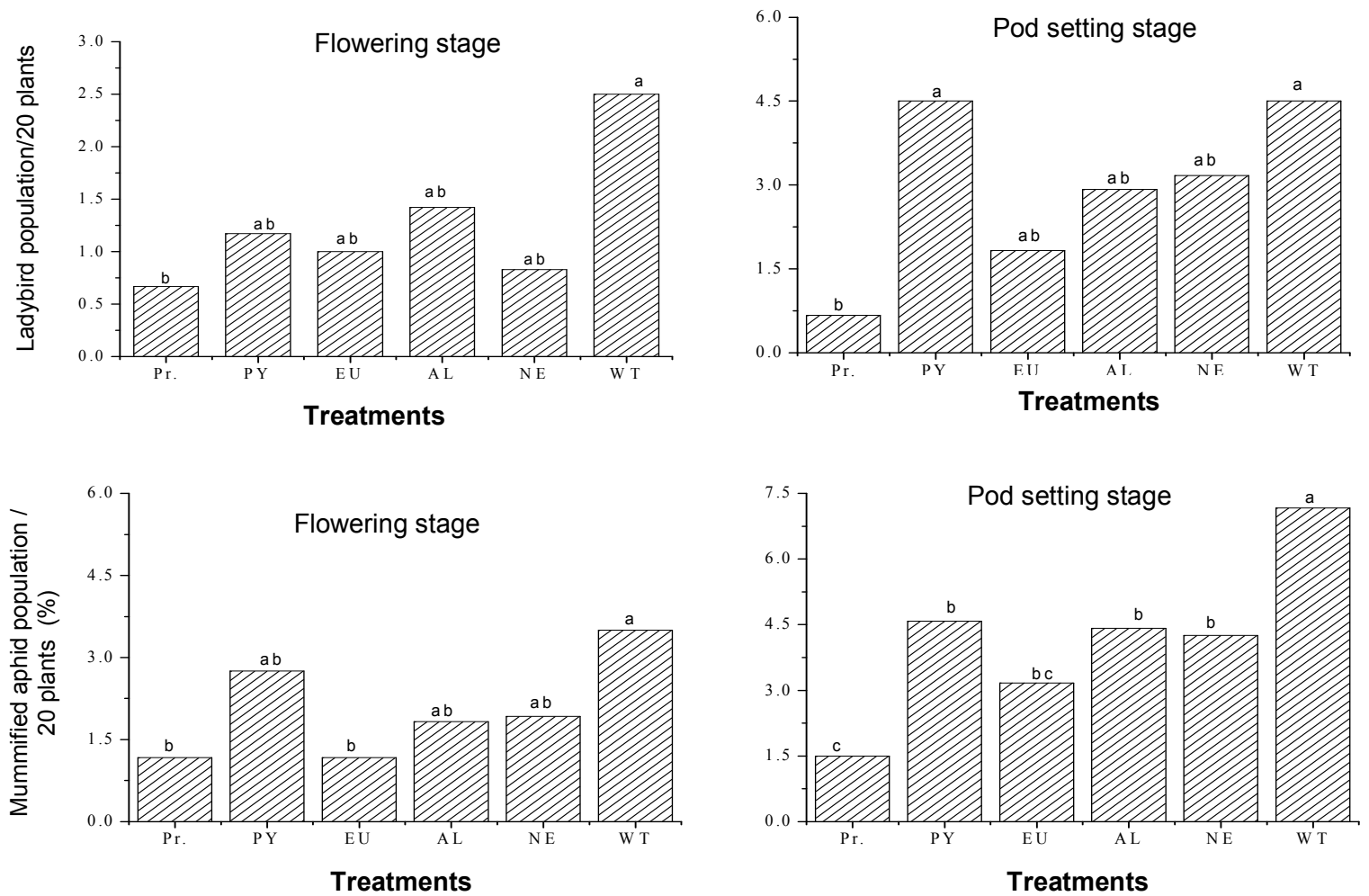

Figure 1: Mean ladybird beetle and mummified aphid population per 20 plants at flowering and pod setting stages treated with four different botanicals $(\mathrm{Pr}=$ Pirimicarb; $\mathrm{PY}=$ pyrethrum; $\mathrm{EU}=$ Eucalyptus; $\mathrm{AL}=$ aloe; $\mathrm{NE}=$ Neem; WT, untreated control);, means were separated using Students Newman Keuls test (SNK).

\section{DISCUSSION}

Results of the study showed that the $10 \%$ application rate or $100 \mathrm{~g} / 1$ liter of all botanicals tested was able to reduce pea aphid population and their damage on field pea. Studies in Egypt have shown that oil extracts from Eucalyptus globulus had a better performance than the organophosphate insecticide Dimethoate against piercing and sucking faba bean insect pests with minimal effect on associated natural enemies including the true spiders and minute pirate bug (Mousa et al., 2013). Mishra et al. (2012) also confirmed the pesticidal potential of $E$. globulus against the stored product insect pests, red flour beetle (Tribolium castaneum) and rice weevil (Sitophilous oryzae). The pesticidal characterstics of extracts from different parts of the neem tree, Azadirachta indica against several pests of crops are well documented (Schmutterer, 1990). Performance of pyrethrum, Chrysanthemum cinerariifolium Trev. was reported to be on par with --synthetic insecticide pyrethroid (Cypermethrin) in controlling field insect pests in ground nut in Nigeria (Frank et al., 2015). Aphid population recorded from 'Tegegnech' at vegetative stage was significantly higher than 'Mohanderfer' which agrees with earlier reports of Kemal (2002). Damage level was significantly lower in Tegegnech than in Mohanderfer despite higher aphid population in Tegegnech indicating the level of tolerance this variety exhibit against this pest which agrees with earlier reports of Kemal (2002).Quisenberry and Schotzko (1994) stated that tolerant plants do not inhibit pest population growth but harbor high pest population densities and give reasonable yield.
Aphid infestation with density of 1 to 3 per plant occurred about a month after planting which agrees with earlier observations of Kemal (1999) who stated that pea aphid population peaks 40 to 50 days after crop emergence coinciding with flowering and pod setting stages of the crop. The observed lower number of predators in the high rate of application than the low rate agrees with reports of Swaminathan et al. (2010). They reported a higher percentage $(73.3 \%)$ of Adonia variegata (Goeze) mortality from a $10 \%$ neem seed kernel extract than a $5 \%$ neem seed oil which caused $65 \%$ mortality. Predation and parasitism were relatively high in the untreated plots, intermediate in botanical treated plots and low in Pirimicarb treatment suggesting that botanicals are safer to the natural enemies of pea aphids. Both predation and parasitism were higher in the low rate treatment than the high rate.

\section{CONCLUSION}

This study found that $10 \%$ application or $100 \mathrm{~g} / 1$ liter of extracts from plant species, namely pyrethrum flower (Chrysanthemum cinerariifolium Trev.), young leaves of Blue Gum (Eucalyptus globulus Labill.), neem seed (Azadirachta indica A. Juss) and matured leaves of Aloe (Aloe pubescens Reynolds) botanicals was able to provide varying degree of protection on pea from pea aphid attack and safer to pea aphid natural enemies than the synthetic insecticide suggesting their potential in the integrated management of the pest (IPM). Their use in pea aphid IPM entails determination of the active substances present in them, improving its formulation and determination of optimum rate and frequency through further study. Although damage level in the tolerant 
Lemmessa Gemmeda \& Gashawbeza Ayalew

variety was less than in the susceptible variety used in this study, both aphid population and damage level were high in the tolerant variety too suggesting the need of identification of resistance sources from screening programs to get a more tolerant or pea aphid resistant variety.

\section{Conflict of Interest}

Authors declared no conflict of interest.

\section{REFERENCES}

Abayneh Esays., Demeke Tafase., Gebeyehu Beley and Kebede Agazegn (2003). Soil of Kulumsa Agricultural Research Center. National Soil Research Center (NSRC), Soil survey and Land Evaluation. Technical Paper No.76.

Asfaw Telaye., Geletu Bejiga., Saxena, M.C., Solh, M.B. (eds), (1994). Cool season food legumes in Ethiopia. Proceedings of the first National cool season food legumes Review conference, 16-20 December 1993, Addis Ababa, Ethiopia. ICARDA/ Institute of Agricultural Research in Dry Area. ICARDA:Aleppo, Syria.Vii.440p.

Bayeh Mulatu (2007). Contact Bioassay of an Endemic plant to Ethiopia on Three Aphid species. Ethiopian journal of Biological Science 6(1):51-52.

Blaine, S. and Endres, G. (2009). Field pea Production. NDSU Extension service. North Dakota State University, Fargo, North Dakota 58108. A-1166. www.ag.ndsu.edu. Accessed on 19, May, 2010.

CSA (Central Statistical Agency), (2012). Report on area and production of crops. Agricultural Sample Survey Vol. 1: Addis Ababa, Ethiopia.

Dodia, D.A., Patel, I.S., Patel G.M. (eds), (2008). Botanical Pesticides for Pest Management. Scientific Publisher, India.

FAO (Food and Agricultural Organization of the United Nations), (1999). FAO production Year book 1999. FAO. Rome, Italy.

Frank, O.O., Sunday, A.D., Gabriel, O.I., Christopher, E.A. and Chinyere, P.O. (2015). Comparative performance of Pyrethrum (Chrysanthemum cinerariifolium Trev) Extract and Cypermethrin on some field insect pests of Ground nut (Arachis hypogaea L.) in Southeastern Nigeria. American Journal of Experimental Agriculture 7(2):96106.

IAR (Institute of Agricultural Research), (1987). Research Progress Report for the Period 1986/87. Holeta Research Centre. IAR, Addis Ababa, Ethiopia.

Kemal Ali (1991). Determination of economic threshold level for pea aphid control. In: Asfaw Telaye, Geletu Bejiga, Saxena. Mohan C. and Solh. Mahmoud B. (eds) 1994.Cool season food legumes in Ethiopia. Proceedings of the first National cool season food legumes Review conference, 16-20 December 1993, Addis Ababa, Ethiopia. ICARDA/ Institute of Agricultural Research in Dry Area. ICARDA:Aleppo, Syria.Vii.440p.

Kemal Ali (2002). An integrated approach to pest Management in field pea (Pisumsativum L.) with emphasis on pea aphid (Acyrthosiphon pisum Harris). A
Sci. Technol. Arts Res. J., April-June 2015, 4(2): 53-58

Ph.D. Thesis, University of the Free State, Bloemfontein, South Africa.313p.

Kemal Ali., ven den, S., Louw, M. and Swart, W.J. (2005) Effects of neem formulation on pea aphid [Acyrthosiphon pisum (Harris)] development and reproduction on field pea in Ethiopia. Ethiopian Journal of Agricultural Science 18: 73-87.

Melaku Wale (2002). Population Dynamics of pea aphid, Acrythosiphon pisum Harris (Homoptera: Aphididae) on field pea (Pisum sativum L.) in northern Ethiopia. Insect Science Application 22(2):131-137.

Melaku Wale (2004). Relative efficacy of some botanicals, detergent and kerosene in controlling the pea aphid Acyrthosiphon pisum (Harris) (Hemiptera:Aphididae) on grass pea Lathyrus sativus. International journal of Tropical insect science 24(2): 143-149.

Mishra, B.B., Tripathi, S.P. and Tripathi, C.P.M. (2012). Repellent effect of leaves essentialoils from Eucalyptus globulus (Mirtaceae) and Ocimum basilicum (Lamiaceae) against two major stored grain insect pests of Coleopterans. Nature and Science 10(2): 50 (Abstract).

MoA (Ministry of Agriculture and Rural Development), (2007). Crop Variety Registry, Issue No. 10. Addis Ababa, Ethiopia.

Mousa, K.M., Khodeir, I.A., El-dakhakhni, T.N. and Yousef A.E. (2013). Effect of Garlic and Eucalyptus oils in comparison to organophosphate insecticides against some piercing - sucking faba bean insect pests and natural enemy population. Egyptian Academic Journal of of Biological Sciences 5(2): 21-27.

Pavela, R. (2009). Effectiveness of some Botanical Insecticides against Spodoptera littoralis Boisduvala (Lepidoptera: Noctudae), Myzus persicae Sulzer (Hemiptera: Aphididae) and Tetranychus urticae Koch (Acari: Tetranychidae). Plant protection Science 45(4): 161-167.

Quisenberry, S. S. and Scbotzko, D.J. (1994). Integration of Plant Resistance with Pest Management Methods in Crop Production Systems. Journal of Agricultural Entomology 11(3): 279-290.

Rajinder, P. and Dhawan, A.K. (eds), (2009). Integrated Pest Management: Innovation- Development Process.V.1. Springer Science.

SAS Institute, (2002). SAS/STAT user's guide. SAS Institute, cary, North carilina, U.S.A.

Schmutterer, H. (1990). Properties and potential of natural pesticides from the neem tree, Azadirachta indica. Annual Review of Entomology 35: 271-297.

Sebsebe Demissew, N. Inger, Stabbetorp E. Odd, 2003. Flowers of Ethiopia and Eritrea. Aloes and other Lilies. Shama books,Addis Ababa, Ethiopia.227p.

Sharma, A. and Gupta, R. (2009). Biological activity of some plant extracts against Pieris brassicae L. Journal of Biopesticides 2(1): 26-31.

Swaminathan, R., Jat, H. and Hussain, T. (2010). Side effects of a few botanicals on the aphidophagous coccinellids. Journal of Biopesticides 3(1): 081-084. 